\title{
Publication rate of abstracts presented in a Brazilian experimental surgery congress ${ }^{1}$
}

\author{
Marcus Vinicius Henriques Brito ${ }^{\mathrm{I}}$, Nara Macedo Botelho", Edson Yuzur Yasojima ${ }^{\mathrm{III}}$, Renan Kleber Costa Teixeira ${ }^{\mathrm{IV}}$, Vitor Nagai \\ Yamaki $^{\mathrm{V}}$, Daniel Haber Feijó ${ }^{\mathrm{VI}}$, Igor Nagai Yamaki ${ }^{\mathrm{VI}}$, Carolina Ribeiro Mainardi ${ }^{\mathrm{VII}}$
}

DOI: http://dx.doi.org/10.1590/S0102-865020160100000009

${ }^{\mathrm{I}} \mathrm{PhD}$, Full Professor, Department of Experimental Surgery, School of Medicine, Universidade do Estado do Pará (UEPA), Belem-PA, Brazil. Conception, design, intellectual and scientific content of the study; critical revision.

IIPhD, Full Professor, Department of Gynecology and Obstetrics, School of Medicine, UEPA, Belem-PA, Brazil. Critical revision.

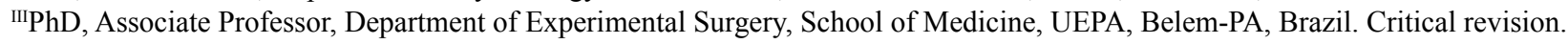

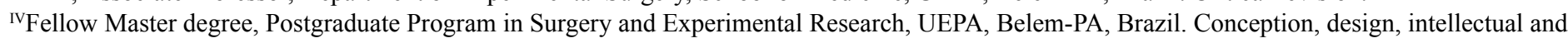
scientific content of the study; interpretation of data; manuscript writing.

${ }^{\mathrm{v}}$ Graduate student, School of Medicine, UEPA, Belem-PA, Brazil. Acquisition and interpretation of data, statistical analysis.

${ }^{\mathrm{V}}$ Graduate student, School of Medicine, UEPA, Belem-PA, Brazil. Manuscript preparation, interpretation of data.

${ }^{\mathrm{VII} M D}$, School of Medicine, UEPA, Belem-PA, Brazil. Acquisition and interpretation of data, manuscript writing.

${ }^{\mathrm{VIII}}$ Graduate student, School of Medicine, UEPA, Belem-PA, Brazil. Acquisition and interpretation of data, manuscript preparation.

\section{ABSTRACT}

PURPOSE: To verify the publication rate of the abstracts presented at the XII Brazilian Congress of Experimental Surgery.

METHODS: We performed a cross-sectional study that evaluated if the abstracts accepted for presentation at the XII Brazilian Congress of Experimental Surgery were published in periodics. The information was acquired using the Scielo, Medline / Pubmed, LILACS and Google Scholar databases.

RESULTS: From all the abstracts presented, only 77 (40.52\%) were published in scientific journals. Of this total, 14 (18.18\%) were published prior to the conference 35 (45.45\%) in the same year that occurred congress, 56 (72.72\%) in the period 2011-2013 and 63 (81, $81 \%$ ) between the Congress and the year 2015. Regarding the geographical distribution of summaries, $42(22 \%)$ were from the northern region, $19(10 \%)$ from the Northeast, 8 (4\%) Midwest, $116(61 \%)$ from the Southeast and $5(3 \%)$ from the south.

CONCLUSION: The publication rate of the abstracts presented at the XII Brazilian Congress of Experimental Surgery was 40,52\%, most from the state of Sao Paulo.

Key words: Abstracts. Publishing. Research. 


\section{Introduction}

One of the great milestones of human history was the development of writing, this comes from the fact that the knowledge passed on orally eventually got lost or was modified over time, and only the civilizations with a type of writing managed to maintain and spread their culture throughout time ${ }^{1,2}$.

Brazil and the world live a great period of growth in the generation of scientific articles, which can be evidenced by the increasing amount of published Brazilian papers. The surgical areas have a prominent position, where there is a 231 times increase, whereas, in medicine as a whole, there is only an increase of 164 times $^{3}$.

At the end of production of a scientific work, one of the products generated are scientific articles, which can be published in scientific journals, presented at conferences or both. The presentation of projects in national or international conferences is a key part of scientific development; in these environments, research lines are presented, preliminary results can be displayed and there is an open discussion between the researcher and other groups $^{4-6}$.

However, if this work is not published, the knowledge generated is limited to participants of the congress, not reaching its full potential and leading to limited scientific progress. Projects end up being remade in different regions due to non-publication of results. In Brazil, it is clear that the published rates in surgical areas Congress vary between 2,9 to $26,6 \%{ }^{6-}$.

Experimental surgery is a basic science that has importance for all science, and could be publish in a variety of journal ${ }^{10}$. Because of its peculiarity to present works that can be more easily published, it is believed that there is a higher publication of abstracts presented at conferences. However, it was not identified articles showing this data. The aim of this study is to verify the publication rate of the abstracts presented at the XII Brazilian Congress of Experimental Surgery.

\section{Methods}

It was conducted a cross-sectional study that evaluated all abstracts accepted for presentation at the XII Brazilian Congress of Experimental Surgery, held in 2011 in the city of Ribeirao Preto, Sao Paulo, Brazil.

A search was made using the Scielo, Medline / Pubmed, LILACS and Google Scholar databases. The full title of the abstract was used as the search variable. If the article was not identified, an additional search through the Lattes platform was performed, using the names of the authors.

From all abstracts, we collected the following information $^{8}$ : general data (identification of the work, class presentation, original title, nationality and geographic location of the service), specific data from the published ones (published title, journal and index location), number of authors and sex of the authors 1 author and last author. The abstracts were evaluated by two experienced and independent examiners. In case there was disagreement between the examiners, a third one was used as a decision. The analysis was performed in November 2015.

Data was organized and analyzed with the help of software BioEstat ${ }^{\circledR} 5.4$ and Excel $^{\circledR} 2010$ and presented as descriptive statistics.

\section{Results}

In the congress, 194 abstracts were presented, however, four had the same title and authors, therefore were excluded from the analysis. Of this total, two summaries were literature review, one was a meta-analysis and 187 were original articles. Regarding the geographical distribution of summaries, 42 (22\%) were from the Northern region, 19 (10\%) from the Northeast, 8 (4\%) Midwest, 116 (61\%) from the Southeast and 5 (3\%) from the South. There were no international abstracts. Table 1 shows the distribution by states. 
TABLE 1 - Distribution of abstracts according to the states.

\begin{tabular}{|c|c|c|c|c|}
\hline States & $\begin{array}{l}\text { Presen- } \\
\text { tations }\end{array}$ & Percentage & $\begin{array}{l}\text { Publica- } \\
\text { tions }\end{array}$ & Percentage \\
\hline Acre & 0 & $0,00 \%$ & 0 & $0,00 \%$ \\
\hline Alagoas & 0 & $0,00 \%$ & 0 & $0,00 \%$ \\
\hline Amapá & 0 & $0,00 \%$ & 0 & $0,00 \%$ \\
\hline Amazonas & 1 & $0,53 \%$ & 0 & $0,00 \%$ \\
\hline Bahia & 3 & $1,58 \%$ & 0 & $0,00 \%$ \\
\hline Ceará & 0 & $0,00 \%$ & 0 & $0,00 \%$ \\
\hline Distrito & 7 & & 7 & \\
\hline Federal & & $3,68 \%$ & & $9,09 \%$ \\
\hline Espírito Santo & 0 & $0,00 \%$ & 0 & $0,00 \%$ \\
\hline Goiás & 1 & $0,53 \%$ & 0 & $0,00 \%$ \\
\hline Maranhão & 10 & $5,26 \%$ & 5 & $6,49 \%$ \\
\hline Mato Grosso & 0 & $0,00 \%$ & 0 & $0,00 \%$ \\
\hline $\begin{array}{c}\text { Mato Grosso } \\
\text { do Sul }\end{array}$ & 0 & $0,00 \%$ & 0 & $0,00 \%$ \\
\hline Minas Gerais & 9 & $4,74 \%$ & 3 & $3,90 \%$ \\
\hline Pará & 40 & $21,05 \%$ & 6 & $7,79 \%$ \\
\hline Paraíba & 0 & $0,00 \%$ & 0 & $0,00 \%$ \\
\hline Paraná & 3 & $1,58 \%$ & 1 & $1,30 \%$ \\
\hline Pernambuco & 3 & $1,58 \%$ & 0 & $0,00 \%$ \\
\hline Piauí & 0 & $0,00 \%$ & 0 & $0,00 \%$ \\
\hline $\begin{array}{l}\text { Rio de } \\
\text { Janeiro }\end{array}$ & 5 & $2,63 \%$ & 1 & $1,30 \%$ \\
\hline $\begin{array}{l}\text { Rio Grande } \\
\text { do Norte }\end{array}$ & 3 & $1,58 \%$ & 2 & $2,60 \%$ \\
\hline $\begin{array}{l}\text { Rio Grande } \\
\text { do Sul }\end{array}$ & 0 & $0,00 \%$ & 0 & $0,00 \%$ \\
\hline Rondônia & 0 & $0,00 \%$ & 0 & $0,00 \%$ \\
\hline Roraima & 0 & $0,00 \%$ & 0 & $0,00 \%$ \\
\hline $\begin{array}{l}\text { Santa } \\
\text { Catarina }\end{array}$ & 2 & $1,05 \%$ & 1 & $1,30 \%$ \\
\hline São Paulo & 102 & $53,68 \%$ & 50 & $64,94 \%$ \\
\hline Sergipe & 0 & $0,00 \%$ & 0 & $0,00 \%$ \\
\hline Tocantins & 1 & $0,53 \%$ & 1 & $1,30 \%$ \\
\hline Brasil & 190 & $100,00 \%$ & 77 & $100,00 \%$ \\
\hline
\end{tabular}

Source: Research protocol

Of the abstracts submitted $16(8 \%)$ were private universities and 174 (92\%) were from public universities. The average of authors per summary was $5.63 \pm 1.90$, ranging from 1 to 10 authors. The total of authors was 1015 , of which $720(70 \%)$ were men and 295 (30\%) were women. The first author was a man in $70 \%$ (134) abstracts and last in $143(75 \%)$ of the articles.

From all the abstracts presented, only 77 (40.52\%) were published in scientific journals. Of this total, 14 (18.18\%) were published prior to the conference $35(45.45 \%)$ in the same year that occurred congress, $56(72.72 \%)$ in the period 2011-2013 and $63(81,81 \%)$ between the Congress and the year 2015. 14 $(18.18 \%)$ were published in international journals.

Among the works published 50 (64.93\%) were from the state of São Paulo, but the Federal District was the only region that managed to publish all papers submitted to the Congress. The ratio of submitted and published works in the Northern region was $17 \%$ in the Northeast $37 \%$, in the Midwest $88 \%, 47 \%$ in the Southeast and the Southern region $40 \%$. There was a significant difference between regions $(p<0.01)$, where the northern region was the least published and the Midwest that more published.

The international publications 13 (92.85\%) came from the state of São Paulo and one from Minas Gerais. All these publications were from public universities.

\section{Discussion}

The importance of abstracts submitted to medical congresses is well known, since it can fast and easily reach many professionals of a certain field of knowledge ${ }^{5,11}$. Also, up to $63 \%$ of the references used in a textbook are from studies that were presented in a congress, despite the lack of data in some abstracts ${ }^{12}$. Nevertheless, the final purpose of a study is to get published in a scientific journal so it can achieve the whole scientific community.

One of the easiest way to assess the quality and influence of the studies that are sent to a congress as abstracts is to evaluate its publication rate. International studies show rates that can range from $34 \%$ up to $61 \%{ }^{12}$. Nationally, some domestic congresses were able to match these rates ${ }^{6,11}$, but in one Brazilian congress of surgery that occurred in 2003, it got as low as 2,6\% .

In our study, we found a publication rate of $40,52 \%$, which is comparable to many international papers and overtakes the Brazilian average, being higher than an 8 years follow up of an orthopedic congress, in which the rate was only $21,7 \%$ and was appointed greater than the few domestic studies in the area that existed so far in $2013^{12}$. So, we cannot discard the possibility of a future increase in the rate found for the congress we assessed, since it can only be considered a four years' rate and it is already shown that there is a $20 \%$ average of increase after 6 years ${ }^{8}$.

Despite being above the general expectations for Brazilian congresses and matching international studies, we still found it to be a low publication rate when the whole potential of the abstracts is assessed. This study didn't address the reasons why more than half of the researches presented couldn't reach publication, and it is possible to assume that all studies sent as abstracts have all that it takes to be published, notwithstanding good or bad results, excluding works with methodological mistakes that can be pointed out in the meeting and corrected afterwards. They all are missing 
only one of the most difficult parts of a paper, which is writing. Assessing this issue, Sprague et al. ${ }^{13}$ performed a research to find what was the main cause the studies presented in an orthopedic meeting were not being published, and he found that $47 \%$ of the researchers claim lack of time.

Clearly there are other factors that can lead to a reduced publication rate, Fernandes et al. ${ }^{9}$ assessed that on his research over a surgery meeting and found that apart from the difficulties inherent in our environment, mainly the lack of time ${ }^{13}$, other factors may be present, such as publication of the work in nonindexed journals; presentation of the works most relevant services at international conferences or specialties; liberal political acceptance of abstracts; origin of non-university centers work; presentation of preliminary results at the congress; failure in the methodology, such as typographical errors in the abstracts, papers published with different titles and changes in the names of the authors 9 .

It was also found a high proportion of abstracts from the Southeast region, where São Paulo alone submitted 53.68\% of the studies. This scientific productivity gap to the other regions is related to the development of Brazil, and was also found in other medical specialties by other authors ${ }^{6,8}$, Andrade et al. ${ }^{8}$ claims it to be a reflection of the high concentration of universities and research centers in the region, attracting large investments and incentives, given that this is the most developed region of the country.

Only with an increase in the not only the public, but also in the private support to other regions, this situation could be overcome. Since the absolute majority of submitted abstracts came from public universities, attracting investments in the private sector could be a challenge for the managers of numerous private universities that are emerging in Brazil in recent years, thus improving the education evaluations on them.

Finally, starting from the assumption that all summary should be published, boosting measures may be done by the management of the congress. Some have already been implemented, such as the publication of full papers submitted for oral presentation, but also the encouragement of translations and improvements of the abstracts presented and perhaps the requirement of prior submission to indexed journals of abstracts sent to the congress, as done by some North American congresses ${ }^{8}$.

\section{Conclusion}

The publication rate of the abstracts presented at the XII Brazilian Congress of Experimental Surgery was 40.52\%, most from the state of Sao Paulo.

\section{References}

1. Timi JRR. The importance of the use of descriptors in medical publications. J Vasc Bras. 2005 Apr;4(2):14-5.

2. Teixeira RKC, Chaves RF, Botelho NM. A importância dos Descritores em Ciência da Saúde. Rev Para Med. 2010 Jan;24(1):56.

3. Guimarães JA. A pesquisa médica e biomédica no Brasil: comparações com o desempenho científico brasileiro e mundial. Ciênc Saúde Coletiva. 2004 Abr;9(2): 303-27.

4. Teixeira RKC, Silveira TS, Botelho NM, Petroianu A. Citação de artigos nacionais: a (des)valorização dos periódicos brasileiros. Rev Col Bras Cir. 2012 Set;39(5):421-4.

5. Oliveira TR. Frequência de publicação de trabalhos científicos apresentados no $9^{\circ}$ Congresso Brasileiro de Dor. Rev Dor. 2012 Mar;13(2):124-7. doi: 10.1590/S1806-00132012000200005.

6. Ejnisman L, Gomes GS, Oliveira RG, Malavolta EA, Gobbi RG, Camargo OP. Taxa de publicação das apresentações no Congresso Brasileiro de Ortopedia e Traumatologia. Acta Ortop Bras. 2013 Set;21(5):285-7. doi: 10.1590/S1413-78522013000500009.

7. Yoshida WB, Holmo NF, Corregliano GT, Baldon KM, Silva NS. Publicações indexadas geradas a partir de resumos de congressos de angiologia e cirurgia vascular no Brasil. J Vasc Bras. 2008 Apr;7(4):293-7.

8. Andrade VA, Carpini S, Schwingel R, Calderan TRA, Fraga GP. Publicação de trabalhos científicos apresentados em Congresso de Trauma no Brasil. Rev Col Bras Cir. 2011 Jun;38(3):172-6. doi: 10.1590/S0100-69912011000300006.

9. Fernandes FAMH, Ventura DE, Del Grande JC. Índice de publicação dos trabalhos apresentados no XXIV Congresso Brasileiro de Cirurgia. Rev Col Bras Cir. 2003 Oct;30(5):392-5. doi: 10.1590/ S0100-69912003000500011.

10. Yamaki VN, Teixeira RKC, Feijo DH, Silva JAC, Botelho NM, Brito MVH. The experimental surgery and your relation with the university: an experience report. Rev Col Bras Cir. 2014 Out;41(5):378-80. doi: 10.1590/0100-69912014005014.

11. Fernandes IA, da Silveira Álvares T, Arteiro SM, Vianna LC, de Araújo CG. Free communication presentations in sport medicine and science meetings and publication in indexed journals. Braz $\mathrm{J}$ Kinanthropometry Human Performance. 2008 Jul 18;10(1):50-5.

12. Forlin E, Fedato RA, Junior WA. Publicação de trabalhos apresentados como temas livres em congresso ortopédico nacional. Rev Bras Ortop. 2013 Jun 30;48(3):216-20.

13. Sprague S, Bhandari M, Devereaux PJ, Swiontkowski MF, Tornetta P, Cook DJ, Dirschl D, Schemitsch EH, Guyatt GH. Barriers to full-text publication following presentation of abstracts at annual orthopaedic meetings. J Bone Joint Surg Am. 2003 Jan 1;85(1):15863. PMID: 12533587.

\section{Correspondence:}

Edson Yuzur Yasojima

Travessa Arciprestes Manoel Teodoro, 772/1102

66015040 Belém-PA Brasil

Tel.: (91)99991-8882

yasojima@globo.com

Received: Jun 28, 2016

Review: Aug 29, 2016

Accepted: Sep 28, 2016

Conflict of interest: none

Financial source: none

${ }^{1}$ Research performed at Laboratório de Cirurgia Experimental, Universidade do Estado do Pará (UEPA), Belem-PA, Brazil. 